\title{
Privacy Protection AND Genetic Research: WHERE DOES THE PUBLIC INTEREST LIE?
}

\author{
UBAKA OGBOGU* $^{*}$ AND SARAH BURNINGHAM**
}

There is significant public interest in the outcomes of genetic research. However, there is also a great deal of concern that genetic research and associated realms will foster the use and disclosure of personal health and genetic information in ways that undermine protected privacy interests. This article proposes that a balance must be struck between legitimate public interests implicated in the collection, use, and disclosure of genetic information for research purposes. The article also explores the tension between the public interest in genetic research and the protection of individual privacy in relation to different policy regimes and reviews existing statutory rules, case law, and administrative decisions on the public interest exception in Canadian privacy law.
L'intérêt public pour les résultats de la recherche génétique est considérable. Cependant, on s'inquiète également fortement du fait que la recherche génétique et les domaines connexes amènent l'utilisation et la divulgation d'information personnelle sur le plan génétique et de la santé de manière à ébranler la protection de la vie privée. Le présent article propose qu'un équilibre soit atteint entre les intérêts légitimes du public impliqué dans la collecte et l'utilisation et la divulgation d'information génétique à des fins de recherche. L'article explore également la tension qui existe entre l'intérêt du public pour la recherche génétique et la protection de la vie privée des individus en ce qui concerne les divers régimes de politiques. $L$ 'article examine les règles en vertu de lois existantes, la jurisprudence et les décisions administratives quant aux exceptions d'intérêt public contenues dans le droit canadien relatif au respect de la vie privée.

\section{TABLE OF ConTENTS}

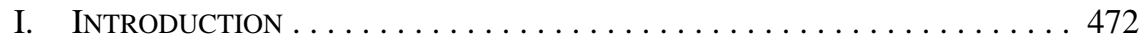

II. OPEn ACCess AS A Public Interest $\ldots \ldots \ldots \ldots \ldots \ldots \ldots \ldots . \ldots . \ldots 43$

III. EMERGING CONSENT POLICIES AND THE

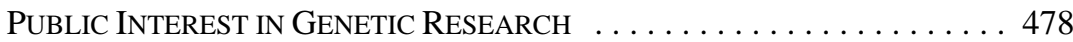

IV. PUBLIC INTEREST CONSIDERATIONS IN CANADIAN PRIVACY

AND ACCESS TO INFORMATION LAW $\ldots \ldots \ldots \ldots \ldots \ldots \ldots$. . . . . . 481

A. The Legal SCOPE of the Public Interest Override $\ldots \ldots \ldots . .481$

B. Public InTEREST Determinations

AND THE BALANCING APPROACH $\ldots \ldots \ldots \ldots \ldots \ldots \ldots . \ldots \ldots 4$

C. The Role of REBS IN HEAlth-RELATED

Public InTEREST DETERMinATIONS $\ldots \ldots \ldots \ldots \ldots \ldots \ldots . \ldots 48$

D. DATA ACCESS COMMITTEES AS AN

AlternAtive APPROACH? . . . . . . . . . . . . . . . . . . . . 489

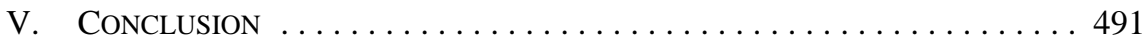

* $\quad$ Assistant Professor, University of Alberta. Research and preparation of this article was made possible by grants from the Office of the Privacy Commissioner of Canada (OPCC) Contributions Program and the Canadian Stem Cell Network. We would like to thank Trudo Lemmens, Lisa Austin, two anonymous peer reviewers for comments on earlier drafts, Nisha Menon for research assistance, and our Health Law Institute team for research and administrative support. We take full responsibility for any errors.

** Research Associate, Health Law Institute, University of Alberta. 


\section{INTRODUCTION}

The collection, use, and disclosure of personal health information for genetic research raises the possibility of conflicts between policies that promote or protect vital public interests in health research and in individual privacy. There is significant public interest in the outcomes of genetic research, which include diagnostic, therapeutic, and preventative health methods and products, early detection of genetic susceptibility to disease, and economic growth through job creation and product revenues. ${ }^{1}$ However, there is also a great deal of concern that genetic research and associated realms, such as cell therapy research and biobanking (that is, the collection and storage of human biological materials and related health information for research use) will foster the use and disclosure of personal health and genetic information in ways that implicate or undermine protected privacy interests. ${ }^{2}$ For example, the practice of allowing open access to genetic research data poses privacy risks for research participants and their genetically-linked kin, ${ }^{3}$ and research studies that depend on long-term storage of genetic materials and information may compromise the privacy interests of donors who cannot (legally or practically) consent to or withdraw from future research use of their samples and information. ${ }^{4}$

As genetic research moves mainstream, a balance needs to be struck between legitimate public interests implicated in the collection, use, and disclosure of genetic information for research purposes. The balance should lie in clear and precise guidance on what constitutes appropriate public interest exceptions and considerations for use and disclosure of protected personal information in this context. While some guidance exists in legal doctrine, ${ }^{5}$ it is not

See e.g. Timothy Caulfield, "Stem Cell Research and Economic Promises” (2010) 38:2 JL Med \& Ethics 303 at 304-305, noting that economic benefits are often used in government documents to justify and promote genetic research funding and that economic justifications might create intense expectations as to whether and when promised benefits will materialize.

2 See Amy L McGuire \& Richard A Gibbs, “No Longer De-identified” (2006) 312 Science 370; Zhen Lin, Art B Owen \& Russ B Altman, “Genomic Research and Human Subject Privacy” (2004) 305 Science 183; William W Lowrance \& Francis S Collins, “Identifiability in Genomic Research” (2007) 317 Science 600; Timothy Caulfield et al, "Research Ethics Recommendations for Whole-Genome Research: Consensus Statement” (2008) 6 PLoS Biology 430.

3 See Genome Canada, Data Release and Resource Sharing (18 September 2008), online: Genome Canada <http://www.genomecanada.ca/medias/PDF/EN/DataReleaseandResourceSharingPolicy.pdf> [Genome Canada, Data Policy]; National Human Genome Research Institute, Reaffirmation and Extension of NHGRI Rapid Data Release Policies: Large-scale Sequencing and Other Community Resource Projects (February 2003), online: Genome Canada <http://www.genome.gov/10506537>; The Wellcome Trust, Sharing Data from Large-Scale Biological Research Projects: A System of Tripartite Responsibility (14 January 2003), online: Genome Canada <http://www.genome.gov/Pages/Research/ WellcomeReport 0303.pdf>; The Wellcome Trust, Policy on Data Management and Sharing (August 2010), online: The Wellcome Trust <http://www.wellcome.ac.uk/About-us/Policy/Policy-and-positionstatements/WTX 035043.htm>; Dave A Chokshi, Michael Parker \& Dominic P Kwiatkowski, "Data Sharing and Intellectual Property in a Genomic Epidemiology Network: Policies for Large-Scale Research Collaboration” (2006) 84:5 Bull WHO 382.

$4 \quad$ See Caulfield et al, supra note 2; Lori Luther \& Trudo Lemmens, "Human Genetic Data Banks: From Consent to Commercialization - An Overview of Current Concerns and Conundrums” in Horst Werner Doelle, J Stefan Rokem \& Marin Berovic, eds, Biotechnology in Encyclopedia of Life Support Systems (Oxford: Eolss Publishers, 2007) 198.

5 In Canada, for example, the question of how to strike an appropriate balance between privacy interests and access to information on grounds of public interests has received considerable attention in privacy and access to information law. See e.g. Canada (Information Commissioner) v Canada (Minister of National Defence), 2011 SCC 25, [2011] 2 SCR 306; Ontario (Public Safety \& Security) v Criminal Trial Lawyers Association, 2010 SCC 23, [2010] 1 SCR 815; Dagg v Canada (Minister of Finance), [1997] 2 SCR 403 [Dagg]. See also McInerney v MacDonald, [1992] 2 SCR 138 (affirming that patients have a right to access their medical records); Frenette v Metropolitan Life Insurance Co, [1992] 1 SCR 647 (patients may waive the right to confidentiality of their medical records). 
clear whether legal rules fully address or anticipate the specific privacy issues associated with genetic research and related fields.

This article examines the tension between the public interest in genetic research and in protection of individual privacy in relation to: (1) policies requiring open access to genetic research outputs; and (2) policies that ease logistical or practical impediments to research by limiting or varying the application of customary consent rules, such as broad or blanket consent ${ }^{6}$ policies and rules that preclude withdrawal of consent past a certain point in the research process. We review existing statutory rules, case law, and administrative decisions on the public interest exception in Canadian privacy and access to information law. Through this review, we explore the legal framework for balancing competing public interests in the domain of genetic and tissue-based research. We conclude with a proposal for improving privacy protection outcomes in this research context.

\section{Open ACCess As A Public InTEREST}

In the last decade, there has been a shift in many fields of scientific research to policies favouring open access to research outputs. ${ }^{7}$ In the genetic research context, the roots of the open access model can be traced back to the Human Genome Project (HGP), which provided free public access to all human genomic sequence information generated from the project with the aims of encouraging research and development and maximizing societal benefits. ${ }^{8}$ The HGP approach emphasized that "human genomic databases are global public goods," and as such, should be accessible to everyone.

Broad or blanket consent refers to consent obtained by asking research participants to agree to participation (e.g. by donating biological material or allowing the use of their personal health information) in as-yet unknown, unforeseen, or unspecified research. It is contrasted with specific consent, which involves consent to participation in known, specified research projects. See Gert Helgesson, "In Defense of Broad Consent” (2012) 21:1 Cambridge Quarterly of Healthcare Ethics 40; Zubin Master et al, "Biobanks, Consent and Claims of Consensus" (2012) 9:9 Nature Methods 885. While broad and blanket consent models generally permit participants to consent to future research, they are distinct concepts. Blanket consent grants researchers the "unrestricted right to use [a participant's] sample/information in any research without any other information," whereas broad consent provides participants with "enough information to understand the general nature" of the research (e.g. genetic research), though not the specific details of the research project they are consenting to (Margaret FA Otlowski, "Tackling Legal Challenges Posed By Population Biobanks: Reconceptualising Consent Requirements" (2012) 20:2 Med Law Rev 191212 at 218).

Peter Suber, "Ensuring Open Access for Publicly Funded Research” (2012) 345:7869 Brit Med J 10; John Whitfield, “Open Access Comes of Age” (2011) 474 Nature 428 . Canada has adopted guidelines from the Organisation for Economic Co-operation and Development (OECD), urging open access to research data from publicly funded projects. See Canada Foundation for Innovation, Research Data (2011), online: Government of Canada <http://www.science.gc.ca/default.asp?lang=en\&n=2BBD98C5$1 \% 3 \mathrm{E}>$; Organization for Economic Co-operation and Development, OECD Principles and Guidelines for Access to Research Data from Public Funding (2007), online: OECD <http://www.oecd.org/sti/scitech/38500813.pdf $>$.

8 HUGO Ethics Committee, "Statement on Human Genomic Databases” (December 2002), online: HUGO $<$ http://www.hugo-international.org/img/genomic_2002.pdf > [HUGO Statement, 2002]; Bartha Maria Knoppers, “Consent to 'Personal' Genomics and Privacy” (2011) 11:6 European Molecular Biology Organization Reports 416; Jane Kaye, "The Tension Between Data Sharing and the Protection of Privacy in Genomics Research” (2012) 13 Annual Review of Genomics and Human Genetics 415 at 417. Jorge Contreras refers to the data generated from the Human Genome Project as the "genome commons" (Jorge L Contreras, "Bermuda's Legacy: Policy, Patents, and the Design of the Genome Commons" (2011) 12:1 Minn JL Sci \& Tech 61 at 63; E Giglia \& A Swan, "Open Access to Data for a New, Open Science" (2012) 48 European Journal of Physical and Rehabilitation Medicine 713). HUGO Statement, 2002, ibid. 
Many funding organizations and government policies mandate open access or data sharing as a condition for receipt of research funding. For example, in the United Kingdom, both the Wellcome Trust and the Medical Research Council require that research papers be made freely available within six months of publication. ${ }^{10}$ The National Institutes of Health (NIH) also requires funded researchers to submit their manuscripts to a free publicly accessible database within 12 months of publication, ${ }^{11}$ and have established a centralized data repository to enable sharing of de-identified ${ }^{12}$ genomic research data. ${ }^{13}$ Many other initiatives around the globe reflect this trend toward open access and sharing of research data. ${ }^{14}$

In Canada, researchers funded by the Canadian Institutes of Health Research (CIHR) are required to provide free public access to peer-reviewed papers within 12 months of publication. ${ }^{15} \mathrm{CIHR}$ also requires researchers to deposit research data in a public database upon publication of research results. ${ }^{16}$ For example, all nucleic acid sequences generated from CIHR-funded projects must be deposited into GenBank, an NIH database of DNA sequences. ${ }^{17}$ Genome Canada, a major national funder of genomics research, similarly requires prompt sharing of data and resources generated from funded research. ${ }^{18}$

Dave Carr \& Robert Kiley, “Open access to science helps us all,” The New Statesman (13 April 2012), online: The New Statesman <http://www.newstatesman.com/blogs/economics/2012/04/open-accessscience-helps-us-all>; The Wellcome Trust, Open Access Policy, online: The Wellcome Trust <http:// www.wellcome.ac.uk/About-us/Policy/Policy-and-position-statements/WTD002766.htm>; Medical Research Council, Open Access Position Statement (January 2013), online: <http:/www.mrc.ac.uk/ Ourresearch/Ethicsresearchguidance/Openaccesspublishing/Positionstatement/index.htm>. Consolidated Appropriations Act, 2008, Pub L No 110-161, § 218 (2007).

"De-identified" means that identifying information (such as name or social insurance number) has been removed. We use the term "de-identified” throughout the article, rather than "anonymized,” which bears an inconsistent meaning in academic literature and policy documents. See generally Bernice S Elger \& Arthur L Caplan, "Consent and Anonymization in Research Involving Biobanks: Differing Terms and Norms Present Serious Barriers to an International Framework” (2006) 7:7 European Molecular Biology Organization Reports 661.

13 National Institute of Health, Department of Health and Human Services, Policy for Sharing of Data Obtained in NIH Supported or Conducted Genome-Wide Association Studies (GWAS), Federal Register (Notice), Vol 72, No 166, P 49290 (28 August 2007), online: National Institute of Health <http://www. grants. nih.gov/grants/guide/notice-files/NOT-OD-07-088.html>.

14 Richard Van Noorden, "New Year, New Science” (3 January 2013) 493 Nature 11; Katie Thomas, "Breaking the seal on drug research" The New York Times (29 June 2013), online: New York Times <http://www.nytimes.com/2013/06/30/business/breaking-the-seal-on-drug-research.html?page wanted=all\&_r=1\&>; Science Europe, Science Europe Position Statement: Principles for the Transition to Open Access to Research Publications (April 2013), online: Science Europe <http://www. scienceeurope.org/uploads/Public\%20documents\%20and\%20speeches/SE_OA_Pos_Statement.pdf>; World Health Organization, International Clinical Trials Registry Platform (ICTRP), online: World Health Organization <http:// www.who.int/ictrp/en/>; European Medicines Agency, Draft Policy 7.0: Publication and Access to Clinical-Trial Data (24 June 2013), online: European Medicines Agency $<$ http://www.ema.europa.eu/docs/en_GB/document_library/Other/2013/06/WC500144730.pdf>; Health Canada, Health Canada's Clinical Trials Database, online: <http://www.hc-sc.gc.ca/dhp-mps/ prodpharma/databasdonclin/index-eng.php>.

15 Canadian Institutes of Health Research, CIHR Open Access Policy (1 January 2013), online: Canadian Institutes of Health Research <http://www.cihr-irsc.gc.ca/e/46068.html> [CIHR Open Access Policy, 2013].

16 Ibid.

17 National Center for Biotechnology Information (NCBI), GenBank Overview, online: NCBI <http:// www.ncbi.nlm.nih.gov/genbank/>.

18 Genome Canada, Data Policy, supra note 3. See also International Society for Stem Cell Research, Guidelines for the Conduct of Human Embryonic Stem Cell Research (21 December 2006), online: International Society for Stem Cell Research <http:/www.forth.gr/_gfx/pdf/ISSCRhESCguidelines 2006.pdf>. See further PL Taylor, "Research Sharing, Ethics and Public Benefit” (2007) 25:4 Nature Biotechnology 398 at 398, which directs researchers "to share research materials, data and intellectual property (IP) rights necessary for published research to be validated and for other scientists to conduct further research.” 
Why are open access policies so prevalent? First, open access promotes the intuitively appealing notion that research funded by the public should be accessible to the public. ${ }^{19}$ Second, open access facilitates faster and wider dissemination of research results, ${ }^{20}$ thus allowing researchers to mine and re-use research data to produce new knowledge without the need to spend more money or time on data collection. ${ }^{21}$ Third, "reduced costs and shortened development cycles [resulting from] ... greater access to ... research outputs”"22 will likely generate economic benefits to the tune of several million dollars while also enabling products to be brought to the market earlier. ${ }^{23}$ Finally, open access promotes equal and just distribution of the benefits of research by encouraging sharing of research outputs and data among "economically and geographically diverse" ${ }^{24}$ scientists and publics. ${ }^{25}$ Open access thus furthers the notion that genetic research is beneficial to everyone.

At the same time, open access and data sharing pose significant privacy concerns for individuals who contribute their biological materials to genetic research. One such concern is that placing sensitive genetic information or data derived from these materials in the public domain increases the possibility of misuse, especially for non-research purposes. Even when genetic information is de-identified, it remains unique to an individual and could potentially be linked to that person (or his or her genetic relatives) if used in conjunction with other personal health information or publicly available information. ${ }^{26}$ Indeed, recent studies have shown that it is possible to re-identify donors of biological material by combining their deidentified genetic data ${ }^{27}$ or DNA samples ${ }^{28}$ with demographic and genealogical information available in the public domain. It should be noted, however, that re-identification currently requires sophisticated technical ability and tools, but it may become more mainstream as databases expand and different data sources linked. ${ }^{29}$

Furthermore, open access enables or promotes uses of genetic research data by those who were not involved in collecting the biological materials from which such data is derived. This situation sidesteps important legal and ethical ties between users and donors, such as the obligation to obtain informed consent. ${ }^{30}$ As one commentator has observed, "[t]he onward sharing of data raises questions about who is accountable not only to research ethics

Bevin P Engelward \& Richard J Roberts, “Open Access to Research Is in the Public Interest” (2007) 5:2 PLOS Biology 48 at 48; CIHR Open Access Policy, 2013, supra note 15 at para 1: “As a publicly funded organization, CIHR has a fundamental interest in ensuring that the findings that result from the research it funds, including research publications and publication-related data, are available to the widest possible audience, and at the earliest possible opportunity." Engelward \& Roberts, ibid at 48. See also CIHR Open Access Policy, 2013, ibid: "Advancements in science and health care are made possible through widespread and barrier-free access to cutting-edge research and knowledge enabling scientists, clinicians, policymakers and the public to use and build on this knowledge."

Giglia \& Swan, supra note 8 at 714.

Carr \& Kiley, supra note 10.

Carr \& Kiley, ibid; Giglia \& Swan supra note 8 at 714.

Taylor, supra note 18 at 398.

Ibid.

John Timmer, “Anonymized genetic research data still carries privacy risks” ARS Technica (6 October 2009), online: ARS Technica <http://arstechnica.com/science/2009/10/anonymized-genetic-researchdata-still-carries-privacy-risks>; Matthew D Mailman et al, "The NCBI dbGaP Database of Genotypes and Phenotypes” (2007) 39:10 Nature Genetics 1181. Lowrance \& Collins, supra note 2; McGuire \& Gibbs, supra note 2; Bradley Malin et al, "Identifiability in Biobanks: Models, Measures, and Mitigation Strategies” (2011) 130 Human Genetics 383.

Kaye, supra note 8 at 419; John Bohannon, "Genealogy Databases Enable Naming of Anonymous DNA Donors” (2013) 339 Science 262.

Kaye, ibid at 420. 
committees approving new research but also to the research participants for the secondary uses of data in other studies." 31 Data sharing and open access approaches thus add "a new twist to the old questions of informed consent, protection of privacy, and governance of medical research." 32

Rationales and justifications used to support open access policies often appeal to public interest considerations. The endorsement of open access on the basis of "the public good" or "the public interest" abounds in policies promoting this research trend. NIH policy, for example, encourages "sharing of ideas, data, and research findings to help accomplish its important public mission to uncover new knowledge that will lead to better health for everyone."33 Similarly, CIHR policy provides:

\footnotetext{
Advancements in science and health care are made possible through widespread and barrier-free access to cutting-edge research and knowledge enabling scientists, clinicians, policymakers and the public to use and build on this knowledge ... CIHR strongly supports unrestricted open access, which promotes the principle of scientific openness, an essential element of science. ${ }^{34}$
}

Genome Canada's Policy on Data Release and Resource Sharing states that "data and resource sharing policy is intended to accelerate the translation of research for the benefit of humankind.”35 At the international level, a report by the Organisation for Economic Cooperation and Development (OECD) promotes open access to data generated from tax-payer supported research on the basis that such research is "a public good, produced in the public interest." 36 This perspective is also endorsed by Research Councils UK, whose Common Principles on Data Policy provide that "[p]ublicly funded research data are a public good, produced in the public interest, [and] should be made openly available with as few restrictions as possible in a timely and responsible manner that does not harm intellectual property." ${ }^{37}$ Clearly open access policies appeal to public interest considerations.

By contrast, privacy considerations have often been treated as an afterthought in the process of developing open access and data sharing policies. For example, during consultation on the initial draft of CIHR's open access policy, researchers expressed concern that the draft did not sufficiently address privacy issues and that its data sharing provisions would likely contravene privacy laws. ${ }^{38}$ Based on this feedback, CIHR revised its policy to require compliance with relevant privacy rules and policies. ${ }^{39}$ Likewise, NIH revised its

Ibid.

Ibid.

National Institutes of Health, "Policy on Enhancing Public Access to Archived Publications Resulting from NIH-Funded Research,” online: OER <http://grants.nih.gov/grants/guide/notice-files/NOT-OD-05022.html>.

CIHR Open Access Policy, 2013, supra note 15.

Genome Canada, Data Policy, supra note 3.

P Arzberger et al, "Promoting Access to Public Research Data for Scientific, Economic, and Social Development” (2004) 3 Data Science Journal 135 at 136.

37 Research Councils UK, RCUK Common Principles on Data Policy, online: Research Councils UK <http://www.rcuk.ac.uk/research/Pages/DataPolicy.aspx> [RCUK Policy].

38 Canadian Institutes of Health Research, CIHR Consultation: Developing a CIHR Access to Research Outputs Policy (4 April 2004), online: Canadian Institutes of Health Research <http://www.cihrirsc.gc.ca/e/33925.html>.

$39 \quad$ CIHR Open Access Policy, 2013, supra note 15 at para 5.1. 
Genome Wide Association Studies (GWAS) policy ${ }^{40}$ to restrict access to certain open access aggregate-level data sets ${ }^{41}$ contained in $\mathrm{dbGaP}$ (the database of Genotypes and Phenotypes) ${ }^{42}$ following requests from scientists and the publication of a study which demonstrated that it was theoretically possible to identify an individual from such data sets. ${ }^{43}$

In both the CIHR and NIH examples, the original open access policy was drafted and implemented without sufficient reflection on or consideration of privacy concerns but was later modified to account for such concerns. ${ }^{44}$ Furthermore, unlike discussions of rationales for open access and data sharing, mentions of privacy risks in current open access and data sharing policies are generally expressed in secondary terms, and there are no references to or discussions of a public interest in privacy protection. This dichotomy signals to those charged with implementing these policies that open access and privacy are not equally weighted public interest objectives and may lead to a decisional bias in favour of data disclosure when resolving conflicts between both public interest objectives. This approach is also at odds with Canadian legal doctrine on what constitutes legitimate justifications for public interest override of protected privacy interests.

Finally, it is important to note that we are not suggesting that open access or data sharing should be discouraged in the genetic research context. Rather, privacy considerations ought to be accorded equal recognition in policies promoting these research goals, particularly in light of research practices and technological innovations that heighten the risk of potential privacy violations. As noted in a recent commentary:

We are at a crucial juncture brought about by the confluence of new technologies for data generation, bioinformatics, and information access on the one hand, which seem to create new risks to privacy, and the public's desire to benefit from these advances for a variety of personal and health reasons on the other hand. In light of this changing landscape, it is time to re-examine how to balance the protection of research

$40 \quad$ National Institutes of Health, Notice of New Process for Requesting dbGaP Access to Aggregate Genomic Data for General Research Use Purposes (10 August 2012), online: National Institutes of Health <http:/grants.nih.gov/grants/guide/notice-files/NOT-OD-12-136.html>; National Institutes of Health, Compilation of Aggregate Genomic Data (27 July 2012), online: National Institutes of Health <http://gd.nih.gov/pdf/Compilation_of_Aggregate_Genomic_Data.pdf>; NCBI, "GaP FAQ Archive,” online: NCBI <http://www.ncbi.nlm.nih.gov/books/NBK36446/\#Geninfo.where_can_i_access_ aggregate_lev>.

41 The term "aggregate-level data sets" refers to pooled data sets containing "summaries of studies and the contents of measured variables as well as original study document text” (NCBI, dbGaP Overview, online: NCBI <http://www.ncbi.nlm.nih.gov/projects/gap/cgi-bin/about.html>). Aggregate-level data can be distinguished from "individual-level data," which includes "de-identified phenotypes and genotypes for individual study subjects, pedigrees [and non-publicly available] pre-computed univariate [one variable] associations between genotype and phenotype" (ibid).

42 NCBI, “dbGaP,” online: NCBI <http://www.ncbi.nlm.nih.gov/gap>.

$43 \quad$ Nils Homer et al, "Resolving Individuals Contributing Trace Amounts of DNA to Highly Complex Mixtures Using High-Density SNP Genotyping Microarrays” (2008) 4:8 PLoS Genetics 1.

44 By contrast, open access policies issued by UK's Medical Research Council (MRC) and Research Councils UK appear to have adopted a "bottom up" approach to incorporating privacy considerations. Both refer to risks posed to personal privacy due to inappropriate release of data, and the MRC policy cross-references its guidance on the use and disclosure of personal information in medical research (Medical Research Council, MRC Policy on Research Data-Sharing, online: Medical Research Council <http://www.mrc.ac.uk/Ourresearch/Ethicsresearchguidance/datasharing/policy/index.htm>; RCUK Policy, supra note 37). 
participants (individuals, families, and groups) with the societal benefits likely to be gained through the enhanced research that broad data sharing facilitates. ${ }^{45}$

\section{EMerging Consent Policies AND THE PUBLIC INTEREST IN GENETIC RESEARCH}

Consent has been called "the cornerstone of contemporary research ethics." ${ }^{46}$ Legal and ethical principles require researchers to obtain consent to specific identifiable research studies from fully informed participants, including individuals who donate biological material for research purposes. These principles also generally allow participants to withdraw from research studies at any time and for any reason. ${ }^{47}$ While these principles are well established and faithfully applied in many research contexts, they pose significant practical and logistical challenges for certain research areas, such as future genetic research studies that rely on stored biological materials or genetic data. ${ }^{48}$ For example, re-contacting and reconsenting donors of such biological material before each research study is likely to be prohibitively expensive or even impractical, especially for studies involving large and diverse collections or populations. ${ }^{49}$

Allowing participants to withdraw consent to use of their biological materials raises similar concerns: withdrawal may be expensive, impossible, or futile if biological material or associated data have been widely shared, used to derive novel products such as stem cell lines, or published in the public domain. There is a further concern that allowing withdrawal from genetic or tissue-based research projects may result in a biased sample or a reduced pool of participants. ${ }^{50}$

In Canada and elsewhere, policy-makers and research institutions have responded to these challenges by adopting policies and practices that run counter to well-established legal and ethical norms, such as rules that allow broad or blanket consent for unknown, future research

45 Laura L Rodriguez et al, “The Complexities of Genomic Identifiablity” (2013) 339 Science 275 at 276. The authors note further: "Although the research community must be realistic and mindful of identifiability concerns, there are also ethical responsibilities to ensure that data contributed by participants for research are maximally utilized and that public research funding stimulates the greatest public good” (ibid).

46 Timothy Caulfield, “The Biobanking Quandary: Getting and Withdrawing Consent” (2011) 12 Harvard Health Pol'y Rev 21 at 21.

47 Ibid. The right to withdraw consent is "a basic tenet of research ethics" and an "almost unqualified right ... found in guidelines throughout the world” (Timothy Caulfield, Ubaka Ogbogu \& Rosario M Isasi, “Informed Consent in Embryonic Stem Cell Research: Are We Following Basic Principles?” (2007) 176:12 Can Med Assoc J 1722 at 1723). For example, UNESCO policy provides that "[w]hen a person withdraws consent, the person's genetic data, proteomic data and biological samples should no longer be used unless they are irretrievably unlinked to the person concerned" (United Nations Educational, Scientific and Cultural Organization (UNESCO), International Declaration on Human Genetic Data, art 9(b)(16 October 2003), online: UNESCO <http://portal.unesco.org/en/ev.php-URL_ID=17720\&URL_ DO=DO_TOPIC\&URL_SECTION=201.html $>$ ).

$48 \quad$ Carlo Petrini, “'Broad” Consent, Exceptions to Consent and the Question of Using Biological Samples for Research Purposes Different from the Initial Collection Purpose” (2010) 70:2 Social Science Medicine 217; Otlowski, supra note 6 at 192-99.

49 Caulfield, supra note 46; Lukas Gundermann \& Ulrich Stockter, "Co-determination of Donors in Biobanks” in Jane Kaye \& Mark Stranger, eds, Principles and Practice in Biobank Governance (Burlington: Ashgate, 2009) 69 at 69-78.

50 Kristina Hug, Göran Hermerén \& Mats Johansson, "Withdrawal from Biobank Research: Considerations and the Way Forward” (2012) 8:4 Stem Cell Reviews and Reports 1056. The authors note empirical evidence is unclear regarding whether these consequences will in fact result if participants withdraw consent (ibid). 
purposes $^{51}$ and policies that preclude withdrawal of consent past a certain point in the research process. ${ }^{52}$ For example, the OECD has endorsed forms of consent "that will permit human biological specimens and/or data to be used to address unforeseen research questions." ${ }^{33}$ Similarly, the World Health Organization has recommended a form of blanket consent "that would allow use of a sample for future genetic research in general, including future as yet unspecified projects." 54 In Canada, the Assisted Human Reproduction Regulations $^{55}$ limit withdrawal of consent to research use of donated embryos to the time before a stem cell line is derived from the embryos. ${ }^{56}$

Such variations to established consent norms are also very likely to compromise privacy protections, as it is doubtful whether, in the absence of an enduring legal or ethical right to consent or withdraw consent, donors and research participants can meaningfully exercise control over the use and disclosure of the "genetic health record" stored in their cells and tissues. $^{57}$

At the same time, de-identification of genetic data prior to research use and sharing is not a panacea for privacy risks for two main reasons. First, there is an emerging policy preference for ongoing linkage of biological material and associated health information for the purpose of ascertaining a donor's health status prior to clinical or therapeutic use of the biological material or products and data derived from it. ${ }^{58}$ Second, as previously discussed, studies have shown that it is possible to re-establish donor identity if de-identified data is combined with other publicly available data. ${ }^{59}$ Also, if research involves a discrete group of donors or participants, de-identification is less likely to provide sufficient privacy protection. ${ }^{60}$ As Jane Kaye neatly sums up, "the traditional focus of privacy protection in

Zubin Master et al, "Biobanks, Consent and Claims of Consensus” (2012) 9:9 Nature Methods 885 at 885.

52 See e.g. Assisted Human Reproduction (Section 8 Consent) Regulations, SOR/2007-137, s 14(2)(e)(iii) [Consent Regulations]. The Consent Regulations were enacted pursuant to the Assisted Human Reproduction Act, SC 2004, c 2, which governs, inter alia, assisted procreation procedures such as fertility treatments and embryo research.

53 OECD, Guidelines on Human Biobanks and Genetic Research Databases, online: OECD <http://www. oecd.org/science/biotech/44054609.pdf $>$ at para 4.6. However, the Guidelines also stipulate that research participants must be "fully informed of the breadth of such consent" and that safeguards be put in place to ensure that participants are protected (ibid).

54 Human Genetics Programme, Proposed International Guidelines on Ethical Issues in Medical Genetics and Genetic Services (December 1997), online: World Health Organization <http://whqlibdoc.who. int/hq/1998/WHO_HGN_GL_ETH_98.1.pdf $>$ at 13.

55 Consent Regulations, supra note 52.

56 Ibid, s 14(2)(e)(iii). It should be emphasized that limitations on withdrawal of consent, while controversial, are not necessarily illegal or unethical. In the privacy law context, fair information principles sometimes justify similar restrictions on withdrawal. For example, it is doubtful that statutory and common law rights of access to personal information encompass a right to request destruction of information.

57 Lawrence O Gostin, “Genetic Privacy” (1995) 23:4 JL Med Ethics 320.

58 Amy Zarzeczny et al, "iPS Cells: Mapping the Policy Issues” (2009) 139:6 Cell 1032 at 1032; National Research Council \& Institute of Medicine, Guidelines for Human Embryonic Stem Cell Research (Washington: National Academies Press, 2005); Eligibility Determination for Donors of Human Cells, Tissues, and Cellular and Tissue-Based Products, 21 CFR §1271.55 (2005).

$59 \quad$ Gymrek et al, supra note 27; Malin et al, supra note 28; B Malin \& L Sweeney, "How (Not) to Protect Genomic Data Privacy in a Distributed Network: Using Trail Re-Identification to Evaluate and Design Anonymity Protection Systems" (2004) 37:3 Journal of Biomedical Informatics 179; Z Lin, AB Owen \& RB Altman, "Genomic Research and Human Subject Privacy" (2004) 305:5681 Science 183.

60 MA Rothstein, "Is Deidentification Sufficient to Protect Health Privacy in Research?" (2010) 10:9 American Journal of Bioethics 17. 
research on consent and anonymization cannot address the concerns raised by data sharing and whole-genome sequences."

Given that the individual's ability to control the use and disclosure of his or her personal information relies largely on specific consent and a robust right of withdrawal, limitations of these principles should at least attract policy reflection and analysis. However, with few exceptions, ${ }^{62}$ the privacy risks flowing from unique consent challenges posed by genetic and tissue-based research has not received much attention in academic and policy discussions. As one commentator observes, "[g]enetic information is not afforded exceptional legal status [in Canada], and is for the most part treated the same way as other personal information in our general data protection regimes.”63 At the same time, Canadians appear to want greater control and protection of their genetic information. For example, in a 2003 survey of 1,200 Canadians, 58 percent of respondents desired stricter regulation of genetic information compared to other health information. ${ }^{64}$

Much like policies promoting open access and data sharing, variations or limitations of established consent norms in the genetic research context are often justified by reference to public interest considerations. Proponents claim that these non-customary consent and withdrawal policies facilitate or aid the realization of the public interest in genetic research, and that potential societal benefits arising from genetic research justify the minimal risk to the participant. ${ }^{65}$ Erik Christensen has argued, for example, that biobank-based research is part of a good society and thus specific informed consent of individuals is not required, as long as the research promotes values and benefits the public can support. ${ }^{66}$ Such appeals to public interest considerations often ignore or fail to mention a possible corresponding public interest in the values flowing from robust consent and withdrawal policies, such as privacy protection and respect for individual autonomy. As we argued in relation to open access policies, this approach underplays or obscures privacy protections at the research policy development and implementation stages. It also begs for an examination of the legitimacy of applying public interest justifications to override or defeat privacy considerations in this context. For example, do public interest justifications for open access and consent variations fit within the definition of acceptable public interest considerations in Canadian privacy and data protection laws? Can policies and institutions promoting or implementing the public

Kaye, supra note 8 at 424

R Alta Charo, "Body of Research-Ownership and Use of Human Tissue" (2006) 355:15 New Eng J Med 1517. For an in-depth analysis of these issues from a privacy/data protection perspective, see Patricia Kosseim \& Dara Jospe, "Banking for the Future: Consent, Confidentiality and Governance Issues in Biobank Research" (Paper submitted at the IV International Seminar on the UNESCO Universal Declaration on Bioethics and Human Rights) (21 January 2011), online: Office of the Privacy Commissioner of Canada <http://www.priv.gc.ca/media/sp-d/2011/sp-d_20110121_pk_e.asp>. Kosseim, "Protecting Genetic Information in Health Research: The Canadian Approach" (lecture delivered in Barcelona, Spain, 25 April 2007), online: Office of the Privacy Commissioner of Canada <http://www.priv.gc.ca/media/sp-d/2007/sp-d_070425_e.asp>.

Pollara Research and Earnscliffe Research and Communications, "Public Opinion Research into Genetic Privacy Issues," Presented to the Biotechnology Assistant Deputy Minister Coordinating Committee, Government of Canada (March 2003), online: <http://www.bioportal.gc.ca/CMFiles/genetic privacypormar2003E49OCT-912004-6986.pdf> at 9 [Pollara Research, "Public Opinion Research"]. For more on this, see Trudo Lemmens \& Lisa Austin, "Privacy, Consent, and Governance" in K Dierickx \& P Borry, eds, New Challenges for Biobanks: Ethics, Law and Governance (Oxford: Intersentia, 2009) 111; Margaret Otlowski, "Developing an Appropriate Consent Model for Biobanks: In Defence of 'Broad' Consent” in Jane Kaye \& Mark Stranger, eds, Principles and Practice in Biobank Governance (Burlington: Ashgate, 2009) 79 at 80-82.

66 Erik Christensen, "Biobanks and Our Common Good" in Jan Helge Solbakk, Soren Holm \& Bjorn Hofmann, eds, The Ethics of Research Biobanking (New York: Springer, 2009) 101. 
interest in genetic research legitimately ignore consideration of privacy issues and solutions? We address these questions in the next and final section of this article by reviewing applicable Canadian legal principles.

\section{PUblic INTEREST CONSIDERATIONS IN CANAdian PRIVACY AND ACCESS TO INFORMATION LAW}

\section{A. The Legal Scope of the Public Interest Override}

Statutory rules governing public interest use and disclosure of protected personal information are fairly uniform throughout Canada. ${ }^{67}$ Applicable provisions generally mandate or permit information custodians (such as public officials) to disclose information that is in the public interest. ${ }^{68}$ Also, in most if not all cases, such disclosure operates as a statutory override of protected privacy rights and interests.

Depending on the jurisdiction and subject matter, the public interest can be invoked to allow the disclosure of information: (1) about risk of significant harm to public safety, public health, or the environment; ${ }^{6}$ (2) for research purposes; ${ }^{70}$ and (3) where the information custodian determines that the public interest in disclosure outweighs a statutory access exemption or any invasions of privacy that would result from such disclosure. ${ }^{71}$ The federal Privacy Act and privacy and access to information statutes in Alberta, British Columbia,

See e.g. Privacy Act, RSC 1985, c P-21, s 8(2)(m); Freedom of Information and Protection of Privacy Act, RSA 2000, c F-25, s 32(1) [AB FIPPA]; Freedom of Information and Protection of Privacy Act, RSBC 1996, c 165, s 25(1) [BC FIPPA]; Right to Information and Protection of Privacy Act, SNB 2009, c R-10.6, ss 28(2), 47 [NB RIPPA]; Access to Information and Protection of Privacy Act, SNL 2002, c A-1.1, s 31(1) [NL AIPPA]; Freedom of Information and Protection of Privacy Act, SNS 1993, c 5, s 31(1) [NS FIPPA]; Freedom of Information and Protection of Privacy Act, RSO 1990, c F.31, s 11(1) [ON FIPPA]; Freedom of Information and Protection of Privacy Act, RSPEI 1998, c F-15.01, s 30(1) [PEI FIPPA]; Freedom of Information and Protection of Privacy Act, SS 1990-91, c F-22.01, s 29(2)(o) [SK FIPPA]; Freedom of Information and Protection of Privacy Act, CCSM c F-175, s 18(4) [MB FIPPA]. The provision in the MB FIPPA applies only as an exception to provisions requiring nondisclosure of information affecting the business interests of thirds parties. Similar public interest overrides non-disclosure of third party business interests exist in other legislation. See e.g. Access to Information Act, RSC 1985, c A-1, s 20(6); SK FIPPA, ibid, s 19(3). Also, there are slight variations in wording among the statutes.

68 See generally ibid.

69 In Alberta, the latter provision has been interpreted as imposing "a statutory obligation on the head of a public body to release information of certain risks under 'emergency-like' circumstances (i.e., 'without delay’)”: Alberta, Information and Privacy Commissioner, Order 98-011 (1 September 1998) (AB IPC) [Order 98-011].

70 Personal Information Protection and Electronic Documents Act, SC 2000, c 5, s 7(3)(f); Privacy Act, supra note 67, s 8(2)(j); AB FIPPA, supra note 67, s 42; Health Information Act, RSA 2000, c H-5, ss 49-55 [AB HIA]; Personal Information Protection Act, SA 2003, c P-6.5, s 20 [AB PIPA]; E-Health (Personal Health Information Access and Protection of Privacy) Act, SBC 2008, c 38, s 15 [BC EHealth Act]; Personal Information Protection Act, SBC 2003, c 63, s 21 [BC PIPA]; BC FIPPA, supra note 67, s 35; Personal Health Information Act, CCSM, c P-33.5, s 24 [MB PHIA]; MB FIPPA, supra note 67, s 47; NB RIPPA, supra note 67, ss 46-47; Personal Health Information Privacy and Access Act, SNB 2009, c P-7.05, s 43 [NB PHIPAA]; NL AIPPA, supra note 67, s 41; Personal Health Information Act, SNL 2008, c P-7.01, s 44 [NL PHIA]; NS FIPPA, supra note 67, s 29; ON FIPPA, supra note 67, s 21; Personal Health Information Protection Act, SO 2004, c 3, s 44 [ON PHIPA]; PEI FIPPA, supra note 67, s 39; c s 29; Health Information Protection Act, SS 1999, c H-0.021, s 29 [SK HIPA].

Alberta, British Columbia, Newfoundland and Labrador, Nova Scotia, Ontario, and Prince Edward Island are examples of jurisdictions that use the override model. The Saskatchewan statute and the federal Privacy Act simply provide that personal information may be disclosed where the "public interest in disclosure clearly outweighs any invasion of privacy that could result from the disclosure" (SK FIPPA, supra note 67, s 29(2)(o); Privacy Act, supra note 67, s 8(2)(m)(i)). 
Nova Scotia, and Prince Edward Island also allow responsible public officials the discretion to identify other reasons for public interest disclosure. ${ }^{72}$

A review of provincial privacy adjudications reveals that the public interest override has been successfully invoked to justify disclosure of: (1) matters of grave or immediate danger to the public or groups of persons, such as risks to public health, public safety, and the environment; ${ }^{73}$ (2) matters of substantial utility or benefit to members of the public, such as improvement of health and health care delivery services; and (3) matters which promote or preserve certain ideas and practices considered to be hallmarks of citizenry, political and social culture, or the democratic process, such as encouraging openness and accountability in government (see generally Table 1).

In relation to research purposes, the public interest override can be relied on to disclose identifying personal information for research purposes without the consent of the individual who is the subject of that information. However, such disclosure is generally only permitted in the following situations: (1) if any record linkage will not cause harm to the identified individual, it is clearly beneficial to the public interest, and efforts are made to remove or destroy individual identifiers at the earliest reasonable time; ${ }^{74}$ or (2) if the public interest in the research outweighs the public interest in privacy protection. ${ }^{75}$ These rules clearly indicate that data de-identification is an important concept in the context of public interest determinations and privacy protections more broadly, especially in situations where the consent of the research subject or participant is not legally required prior to use or disclosure of personal information.

Provinces with health information protection legislation ${ }^{76}$ typically empower research ethics boards (REB) to assess if and when the public interest override should apply to

72 Privacy Act, ibid. The wording of the Ontario and Newfoundland provisions seem to restrict the scope of public interest only to risks posed to public health, public safety, or the environment. It is doubtful that information custodian in these jurisdictions possess any residual discretion to identify other public interest objectives. See ON FIPPA, supra note 67, s 11(1); NL AIPPA, supra note 67, s 31(1). In Alberta, the Privacy Commissioner has interpreted "other reason" in the AB FIPPA to include disclosure for "scientific monitoring and research" (Alberta, Information and Privacy Commissioner, Order F2012-14 (29 June 2012)).

$73 \quad$ See generally supra notes 69, 71 and accompanying text. See also Clubb v Saanich (District), [1996] BCJ no 218 (QL), 46 CR (4th) 253 (BCSC) at para 33 [Clubb], where Justice Melvin held that "[t]he public is, however, truly 'interested' in matters that may affect the health or safety of children.” See also RJR MacDonald Inc v Canada (Attorney General), [1994] 1 SCR 311 at 344, where Justices Sopinka and Cory (interpreting the meaning and scope of the phrase "public interest" in the context of an interlocutory relief application) state: “'Public interest' includes both the concerns of society generally and the particular interests of identifiable groups.”

$74 \quad$ AB FIPPA, supra note 67, s 42; BC FIPPA, supra note 67, s 35; MB FIPPA, supra note 67, s 47(4); NS FIPPA, supra note 67, s 29; NL AIPPA, supra note 67, s 41; NB RIPPA, supra note 67, s 47(6); PEI FIPPA, supra note 67, s 39; Access to Information and Protection of Privacy Act, RSY 2002, c 1, s 38; Access to Information and Protection of Privacy Act, SNWT 1994, c 20, s 49 [NWT AIPPA]; Nunavut Act, SC 1993, с 28, s 29.

75 See AB HIA, supra note 70, s 50(1); BC E-Health Act, supra note 70, s 14(2.1)(d); MB PHIA, supra note 70, s 24(3)(a); NB PHIPAA, supra note 70, s 43(3)(a); ON PHIPA, supra note 70, s 44(3)(c); SK HIPA, supra note 70, s 29. The Ontario provision envisages a balancing of the "public interest in conducting the research and the public interest in protecting the privacy of the individuals whose personal health information is being disclosed": ON PHIPA, ibid, s 44(3)(c). The statutes in Manitoba, New Brunswick, and Saskatchewan do not mention "public interest”: the statutes in Manitoba and New Brunswick require instead that the research be "of sufficient importance to outweigh the intrusion into privacy that would result from the disclosure of personal health information" (MB PHIA, ibid, s 24(3)(a); NB PHIPAA, ibid, s 43(3)(a)). The Saskatchewan legislation provides that "the potential benefits of the research project clearly outweigh the potential risk to the privacy of the subject individual” (SK HIPA, ibid, s 29(2(c)). Alberta, Ontario, Saskatchewan, Manitoba, British Columbia, New Brunswick, and Newfoundland. 
disclosure for health research purposes. ${ }^{77}$ Alberta's Health Information Act, for example, mandates that REBs assess whether "the public interest in the proposed research outweighs to a substantial degree the public interest in protecting the privacy” of personal health information. ${ }^{78}$ The Act also contains a non-exhaustive list of factors that REBs should consider in making public interest determinations for health research disclosure purposes, including the degree to which the proposed research may aid "a) identification, prevention or treatment of illness or disease, b) scientific understanding relating to health, c) promotion and protection of the health of individuals and communities, d) improved delivery of health services, or e) improvements in health system management." ${ }^{\text {,79 }}$ Other provinces do not provide similarly detailed criteria for interpreting public interest.

The public interest objective that provides the basis for a privacy override must also be "significant," “compelling," or "of sufficient importance." ${ }^{\text {" } 0}$ While the statutes provide no further explanation of these terms, interpretive clues abound in case law and privacy adjudications. A few examples are highlighted below.

In Ontario Information and Privacy Commissioner (ON IPC) Order P-984, ${ }^{81}$ Adjudicator Holly Big Canoe considered the meaning of the phrase "compelling” in the wording of the public interest override provision in Ontario’s FIPPA and concluded as follows:

\footnotetext{
"Compelling” is defined as "rousing strong interest or attention"... [T]he public interest in disclosure of a record should be measured in terms of the relationship of the record to the Act's central purpose of shedding light on the operations of government. In order to find that there is a compelling public interest in disclosure, the information contained in a record must serve the purpose of informing the citizenry about the activities of their government, adding in some way to the information the public has to make effective use of the means of expressing public opinion or to make political choices. ${ }^{82}$
}

To summarize, in the context of Ontario's FIPPA, the public interest basis for a privacy override should reflect the aims of the governing legislation and relate to matters that the general public would have a strong interest in knowing about. ${ }^{83}$

See generally supra note 70 . Recent personal health information access and privacy protection legislation in British Columbia vests the responsibility for review of research protocols requiring disclosure in a Data Stewardship Committee (DSC) made up of members drawn from a wider range of stakeholders than traditional research ethics review committees, and members will receive remuneration for their services. See generally BC E-Health Act, supra note 70, ss 14-15. AB HIA, supra note 70 , s 50(1)(b)(i).

Ibid, s 50(2)(a)-(e).

Actual language or term used varies by province.

Order P-984 (28 August 1995).

Ibid. See also In the Matter of an Adjudication Under Section 62, requested by [G.R.] on April 22, 1996 Adjudication Order No 3 (20 June 1997), online: BC IPC <http://www.oipc.bc.ca/rulings/ adjudicators. aspx $>$ [Adjudication Order No 3], where Justice Levine found that the word "clearly" in s 25 of the $B C$ FIPPA (the equivalent provision to s 23 of the ON FIPPA) meant "[o]bvious, beyond reasonable doubt; perspicuous; plain.”

$83 \quad$ Order P-984, supra note 81. See also Clubb, supra note 73 at para 33, where Justice Melvin noted that the term "public interest" in s 25(l)(b) of the BC FIPPA "cannot be so broad as to encompass anything that the public may be interested in learning ... [and] is not defined by the various levels of public curiosity." 
By way of example, in Ontario IPC Order PO-2516, ${ }^{84}$ the parents of a suicide victim claimed there was a compelling public interest in the disclosure of police investigation reports (which included witnesses' personal information) about the death of their son. According to the parents, the public interest basis lay in the public's right to know the true circumstances of their son's death, which allegedly occurred in the presence of four police officers. They also claimed the requested information was necessary to refute the public attribution of the cause of death to suicide, and that police opposition to disclosure created suspicion and was likely to hurt public confidence in the administration of justice. The Attorney General of Ontario opposed the claim, citing a public interest in non-disclosure that was necessary to protect the integrity of police operations and ensure an environment in which an independent investigative body could review the actions of the police officers involved. Adjudicator Holly Big Canoe found that the appellants' interest in disclosure was of a purely private nature, and held that "[a] public interest does not exist where the interests being advanced are essentially private in nature." 85 She also noted that her decision would have been different if "a private interest in disclosure raises issues of more general application." 86

Likewise, in the ON IPC Order P-984, the adjudicator rejected a claim for public interest disclosure of records relating to the hiring of a contractor to establish a Local Area Network because the requested records would not "contribute in any meaningful way to the public's understanding of the activities of government."

In British Columbia, the statutory provision that allows information custodians to disclose information in the public interest has also been interpreted as requiring disclosure of information that is of interest to "the public at large [or to] a group of individuals." ${ }^{88}$ In one case, the adjudicator refused to apply the public interest override to order disclosure of records that were shown to be of interest only to the parties involved in the application. ${ }^{89}$

The Privacy Commissioner of Alberta reached a similar conclusion in a 1996 adjudication concerning an application for a fee waiver on grounds that the requested disclosure was in the public interest. Ruling on the application, the Commissioner stated:

It is possible to have the term "public" apply to everyone ("the public good") and to anyone (John or Jane Public who are the objects of government programs and policies). Similarly "interest” can range between individual curiosity and the notion of interest as a benefit, as in a collective interest in something. The weight of public interest will depend on a balancing of the weights afforded "curiosity," "benefit" and "broad" versus "narrow" publics. Where an access request relates to a matter that is of "interest" in both the sense of curiosity and benefit and the relevant "public" is broad, the case for removing all obstacles to access is very strong. So a matter that is the subject of curiosity to the larger public and also relates to a benefit to the broad public would present a very strong case for the waiver of fees. A matter which is of curiosity to many but affects no general benefit would present a less compelling case. Similarly, a matter that affects a benefit

Ontario Information and Privacy Commissioner, Order PO-2516 (30 October 2006) IPC, online: ON IPC $<$ http://www.ipc.on.ca/images/findings/up-po_2516.pdf >

Ibid at 7.

Ibid.

Order P-984, supra note 81 at 5.

Adjudication Order No 3, supra note 82 at para 84.

Ibid. 
but in which few citizens are interested may present a less compelling case. In the less compelling cases, the importance of respecting the integrity of the legislated fee structure could outweigh the public interest dimension. $^{90}$

Subsequent orders from privacy adjudications in the Province of Alberta also provide useful guidance. For example, in Alberta IPC Order F2006-032, ${ }^{91}$ Adjudicator Christina Gauk outlined comprehensive criteria for assessing whether a record relates to a matter of public interest (see Box A), ${ }^{92}$ including factors such as the extent to which the records contribute to transparency and accountability in government and to public understanding and debate and the applicant's motivation for seeking public interest disclosure.

Finally, the provision in Alberta's FIPPA allowing disclosure of information about risk of significant harm to public safety, public health, or the environment has been interpreted as imposing "a statutory obligation on the head of a public body to release information of certain risks under 'emergency-like’ circumstances (that is, 'without delay').”93 Adjudicators have stated that the public interest override "must be defined narrowly" "94 and can only apply to disclosure where there is "some actual risk ... [or] some evidence that the harm in question is significant."95

\section{B. Public InTEREST Determinations AND THE BALANCING APPROACH}

Before granting access to protected information on public interest grounds, a custodian or designated decision-maker must balance the specific public interest consideration permitting disclosure with the general public interest in protecting affected privacy interests. Applicable statutory rules, ${ }^{96}$ judicial precedents, and administrative law rulings support this interpretation. In Dagg v. Canada (Minister of Finance), for example, Justice LaForest observed that "the Access to Information Act and Privacy Act have equal status" "Parliament did not intend access to be given preeminence over privacy" 98 and that "the collective purpose of ... [access to information and privacy] legislation is to provide

Alberta, Treasury Department, Order 96-002 (21 March 1996) at 15-16.

Alberta, Office of the Information and Privacy Commissioner, Order F2006-032 (2 March 2007).

This is a revision of earlier criteria formulated in Order 96-002, supra note 90. The revised criteria have been applied in Alberta, Office of the Information and Privacy Commissioner, Order F2010-004 (6 July 2010); Alberta, Office of the Information and Privacy Commissioner, Order F2010-005 (13 July 2010); Alberta, Office of the Information and Privacy Commissioner, Order F2012-16 (11 July 2012).

Order 98-011, supra note 69 at para 154. See also Alberta, Office of the Information and Privacy Commissioner, Order F2012-14 (29 June 2012).

Alberta, Information and Privacy Commissioner, Order 96-011 (11 September 1996) at 17.

Ibid at 18.

Ontario, Information and Privacy Commissioner, Order PO-1779 (5 May 2000) at 24:

In all the circumstances, based on the very compelling nature of the public interests that are at stake, and subject to a number of exceptions to protect personal privacy, I am of the view that the compelling public interest in disclosure of the records at issue clearly outweighs the purpose of the section 21 exemption, including the important public policy basis for that exemption relating to the protection of individual privacy.

See also Tom Mitchinson, “‘Public Interest’ and Ontario’s Freedom of Information and Protection of Privacy Act,” Lecture to British Columbia Law Society's Continuing Education Program (16 February 2001), online: ON IPC < http://www.ipc.on.ca/english/Resources/Presentations-and-Speeches/Present ation-and-Speeches-Summary/?id=89>.

Dagg, supra note 5 at para 55 (LaForest J, dissenting). The majority (per Cory J) concurred on this point (ibid at para 1).

Ibid at para 51 . 
Canadians with access to information ... without unduly infringing individual privacy."99 This balancing approach has also been endorsed by dicta in lower court decisions ${ }^{100}$ and provincial privacy adjudications. In Ontario IPC Order P-1398, ${ }^{101}$ for example, a journalist relied on the public interest override in Ontario Freedom of Information and Protection of Privacy Act to challenge the refusal by the Minister of Finance to grant access to records relating to "all documents on the economic, social [and] Ontario budget impacts of Quebec independence compiled since January 1, 1995.” Ruling on the challenge, Inquiry Officer John Higgins stated:

If a compelling public interest is established, it must then be balanced against the purpose of any exemptions which have been found to apply. Section 23 recognizes that each of the exemptions listed, while serving to protect valid interests, must yield on occasion to the public interest in access to information which has been requested. An important consideration in this balance is the extent to which denying access to the information is consistent with the purpose of the exemption. ${ }^{102}$

The public interest override in British Columbia's FIPPA has similarly been interpreted as requiring "an assessment of the public interest in disclosure versus the public interest in nondisclosure.” ${ }^{103}$

The foregoing review indicates that the legal threshold for the public interest override is generally high, and only permits disclosure of matters that address the aims of governing legislation or are of established relevance to a general or significant proportion of the public. Existing interpretations also emphasize a narrow reading of relevant statutory provisions, invoking the override only in circumstances where the information sought will address actual

Ibid at para 97. See also HJ Heinz Co of Canada v Canada (Attorney General), 2006 SCC 13, [2006] 1 SCR 441 at paras 26, 31:

The intimate connection between the right of access to information and privacy rights does not mean, however, that equal value should be accorded to all rights in all circumstances. The legislative scheme established by the Access Act and the Privacy Act clearly indicates that in a situation involving personal information about an individual, the right to privacy is paramount over the right of access to information, except as prescribed by the legislation.

It is apparent from the scheme and legislative histories of the Access Act and the Privacy Act that the combined purpose of the two statutes is to strike a careful balance between privacy rights and the right of access to information. However, within this balanced scheme, the Acts afford greater protection to personal information. By imposing stringent restrictions on the disclosure of personal information, Parliament clearly intended that no violation of this aspect of the right to privacy should occur.

In Ontario Hydro v Mitchinson, [1996] OJ no 4636 (Div Ct) (QL), leave to appeal refused [1997] OJ no 694 (CA) (QL) [Ontario Hydro], the Ontario Divisional Court noted that, in deciding whether there is a compelling public interest, it is necessary to "take into account the public interest in protecting the confidentiality" of the information (ibid at para 1).

Ontario, Information and Privacy Commissioner, Order P-1398 (27 May 1997) (ON IPC), upheld on judicial review, Ontario (Ministry of Finance) $v$ Ontario (Information and Privacy Commissioner), [1999], OJ no 484 (QL), 118 OAC 108 (ONCA).

102 Ibid at 6. See also Ontario, Information and Privacy Commissioner, Order PO-2224 (9 January 2004) at 26, where, the adjudicator, dealing with a refusal by Ontario's Ministry of Health and Long-Term Care to disclose records relating to assessment of diagnostic clinics, held that the public interest override in the Ontario FIPPA requires a consideration of "both the existence of any compelling public interest in disclosing the records and any public interest in keeping them confidential.” See also Order P-984, supra note 81 at 4-5, where the adjudicator held that, once a compelling public interest is established, "it must be balanced against the purpose of the exemption which has been found to apply," keeping in mind "the principle of severability and the extent to which withholding the information is consistent with the purpose of the exemption." 
or immediate rather than speculative concerns, and balancing its likely effects with the public interest in protecting privacy. ${ }^{104}$

While it seems clear that the open access and consent policies discussed above may legitimately be justified by reference to the public interest in facilitating research that is useful or beneficial to the public, our review of Canadian legal principles also makes it clear that public interest justifications affecting privacy interests attract real legal obligations and cannot be used merely as rhetorical flourish or without due consideration of protected privacy rights and interests. Where public interests that affect privacy concerns are invoked in policy development and implementation, a legal obligation exists to ensure that the public interest in research is truly compelling and of pressing relevance to established public aims, and that the corresponding public interest in privacy protection is addressed and given equal consideration. It is essential that privacy be viewed properly — as a public interest in its own right — rather than just a hurdle that must be overcome to promote other public interests (for example, public benefits accruing from open access policies). Privacy considerations should be built into genetic research policies from conception, rather than as an afterthought appended to an existing regulatory framework or as a response to privacy threats or violations. Additionally, the expansion of publicly accessible databases containing identifying personal information means that privacy risks must be assessed in this broader context, rather than within the narrow confines of isolated or single research projects or activities. $^{105}$

In seeking to promote public interest objectives that ease logistical or practical hurdles to genetic research, policy deliberations should also give equal or corresponding consideration to the degree to which the research and associated governance norms serve the public interest in privacy protection. The deliberative process, which is likely to be based on case-by-case assessment, should reflect appropriate balancing of the public interest in privacy with the public interest in genetic research. Such balancing should take into account the sensitive nature of genetic information and the unique implications of inappropriate disclosure for both donors of biological material and their genetic kin. ${ }^{106}$ Indeed, Canadian research ethics guidelines currently require that researchers (and REBs) ensure that an appropriate plan is in place for managing information revealed through genetic research and its implications for participants and their biological relatives. ${ }^{107}$ Similarly, public opinion surveys suggest that Canadians believe genetic information should attract added or heightened privacy protection. $^{108}$

Protection of individual privacy is not just a public interest objective, but also a fundamental value that is protected by the Canadian Charter of Rights and Freedoms, Part I of the Constitution Act, 1982, being Schedule B to the Canada Act 1982 (UK), 1982, c 11, in the right to be free from unreasonable searches and seizures. See Hunter v Southam Inc, [1984] 2 SCR 145. Kaye, supra note 8 at 424 .

106 PA Roche \& GJ Annas, "Protecting Genetic Privacy” (2001) 2:5 Nature Reviews Genetics 392; Amy Zarzeczny et al, "iPS Cells: Mapping the Policy Issues” (2009) 139:6 Cell 1032 at 1032. Canadian Institutes of Health Research, Natural Sciences and Engineering Research Council of Canada, and Social Sciences and Humanities Research Council of Canada, Tri-Council Policy Statement: Ethical Conduct for Research Involving Humans, December 2010, art 13.2 [TCPS].

Timothy Caulfield, "Biobanks and Blanket Consent: the Proper Place of the Public Good and Public Perception Rationales” (2007) 18:2 King's Law Journal 209 at 221-22; Pollara Research, "Public Opinion Research,” supra note 64 at 9; D Kaufman et al, "Public Opinion about the Importance of Privacy in Biobank Research” (2009) 85 American Journal of Human Genetics 643. However, the notion that genetic information is "unique" or different from other personal or health information is contested in the literature: see e.g. Ken M Gatter, "Genetic Information and the Importance of Context: 
Other considerations that should be taken into account in the balancing process include: whether proposed research benefits have materialized or are likely to materialize in the near future ${ }^{109}$ the level of public trust in the research endeavour; ${ }^{110}$ and empirical evidence on research participants' perspectives regarding research use and disclosure of their genetic information. ${ }^{111}$

The foregoing observations indicate that public interest determinations in this context require a good working knowledge of applicable legal rules and of the unique and general privacy risks and challenges associated with the use, disclosure, and sharing of genetic information. These matters, in turn, arguably demand dedicated mechanisms charged chiefly with responsibilities of balancing competing public interests in the health research arena, monitoring emerging privacy concerns flowing from technological advances, and fashioning appropriate responses to such concerns. Given that the responsibility for making public interest determinations in the context of health research currently falls to institutional REBs, one must inquire into whether they are properly placed to perform these roles.

\section{THE ROLE OF REBS IN HEALTH-RELATED Public INTEREST DETERMINATIONS}

In Canada, the composition of biomedical research REBs does not specifically include a privacy law expert, but does include at least one member knowledgeable in law and ethics respectively. ${ }^{112}$ However, the mandated size and composition of the boards are a minimum requirement. Institutions, therefore, have the flexibility to appoint additional members to fulfil capacities in specified areas, including law and ethics. ${ }^{113}$ While this approach allows REBs room for dedicated or as-needed expertise in privacy matters, it is doubtful that it will be employed in practice to retain a privacy expert to fill the mandatory law position or a gap in expertise, unless of course in the highly unlikely event that research protocols requiring such expertise are the central focus of a particular REB. More generally, the fact that REBs are primarily composed of members affiliated with the institution that appointed them and are sometimes involved in the research protocols they review raises questions about whether they are sufficiently at arm's length to implement policies that may affect research progress.

Implications for the Social Meaning of Genetic Information and Individual Identity” (2003) 47 Saint Louis University Law Journal 423; P Kakuk, “Genetic Information in the Age of Genohype” (2006) 9:3 Medicine Healthcare \& Philosophy 325.

Roger Collier, “Popping the Genetics Bubble” (2012) 184:6 Can Med Assoc J 637.

For more on this topic, see Christine Critchley, "Public Opinion and Trust in Scientists: The Role of the Research Context, and the Perceived Motivation of Stem Cell Researchers" (2008) 17:3 Public Understanding of Science 309; Christine R Critchley et al, "Predicting Intention to Biobank: A National Survey” (2012) 22 European Journal of Public Health 139; Timothy Caulfield, Christen Rachul \& Erin Nelson, "Biobanking, Consent, and Control: A Survey of Albertans on Key Research Ethics Issues" (2012) 10:5 Biopreservation and Biobanking 433. But see also Daryl Pullman et al, "Personal Privacy, Public Benefits, and Biobanks: A Conjoint Analysis of Policy Priorities and Public Perceptions” (2012) 14:2 Genetics in Medicine 229.

See e.g. Phoenix Strategic Perspectives Inc, “Survey of Canadians on Privacy-Related Issues,” Report prepared for the Office of the Privacy Commissioner of Canada (January 2013), online: Office of the Privacy Commissioner of Canada <http://www.priv.gc.ca/information/por-rop/2013/por_2013_01_e. pdf $>$ at 37 .

TCPS, supra note 107 , art 6.4 .

Ibid. 
Furthermore, REBs are notoriously overworked and chronically underfunded. ${ }^{114}$ Members usually serve on a volunteer basis, in addition to various primary work responsibilities. The scope of their involvement in the REB also involves fairly extensive and ongoing familiarity with numerous research ethics, laws, policies, and guidance documents. In a sense, it takes “a jack of all trades” rather than a specialist to serve on an REB. These structural problems may also pose challenges to recruiting appropriate experts to address niche issues and concerns.

Finally, REBs have also been criticized for having "ethical tunnel vision," 115 a term that describes a situation where ethics oversight bodies simply follow and apply the procedures and standards set out in ethical guidelines without reflecting on issues raised by and in their work. ${ }^{116}$ As one commentator explains, "the ethics review process by the REB has come to be, in the minds of the major institutional actors and their constituents, a surrogate for a comprehensive ethical approach to research involving human subjects." ${ }^{117}$ A characteristic practice in this regard is when REBs substitute comprehensive ethical review with bureaucratic processes such as reviewing consent forms. ${ }^{118}$ As Michael McDonald has observed:

[E]thics is funnelled into a bureaucratic process, and the process itself is reduced to a bare minimum. That bare minimum consists of the tangible parts — consent forms and other items, like adverse incident reports. Harms are reduced to simple measures of pain, morbidity and mortality. An important general result of this funnelling and narrowing down of ethical concerns is that important issues are missed at all levels and at all stages. For example, the focus on consent forms tends to distract attention from the realities of consent that for example, many subjects neither heed nor even read consent forms. ${ }^{119}$

To summarize, these critiques raise doubts regarding whether REBs are well positioned to undertake substantive review functions, especially ones that involve significant application of and deliberation on statutory rules and areas of specialized knowledge, such as public interest determinations.

\section{DATA ACCESS COMMITTEeS as AN Alternative Approach?}

Given the stated problems with REB involvement in making privacy-related decisions, an alternative strategy may be to establish data access committees (DACs) specifically designed to tackle privacy matters in the context of health research. The composition of such committees should include experts in privacy and access to information law and in relevant

Kathleen C Glass, "Questions and Challenges in the Governance of Research Involving Humans: A Canadian Perspective" in Duff R Waring \& Trudo Lemmens, eds, Law and Ethics in Biomedical Research: Regulation, Conflict of Interest and Liability (Toronto: University of Toronto Press, 2006) 43.

Michael McDonald, The Governance of Health Research Involving Human Subjects (HRIHS), Study prepared for the Law Commission of Canada (May 2000) at 296; Marie Hirtle, "The Governance of Research Involving Human Participants in Canada” (2003) 11 Health LJ 137 at 144-45. Ibid.

Michael McDonald, “Canadian Governance of Health Research Involving Human Subjects: Is Anybody Minding the Store" (2001) 9 Health LJ 1 at 8.

Hirtle, supra note 115 at 144, 150; McDonald, supra note 115 at 299.

McDonald, ibid. 
areas of research, as well as independent members. The committees can also be positioned to tackle policy development and reform functions, including monitoring developments in health research and formulating model policy.

British Columbia has adopted this approach in legislation governing the collection, use, and disclosure of information held in health information banks. ${ }^{120}$ The legislation establishes and empowers a Data Stewardship Committee (DSC) to review requests for and authorize the disclosure of protected health information for health research purposes. The Committee is also charged with broad powers to "establish policies and procedures respecting the disclosure of information"121 under the Act and to make recommendations to the Minister against the issuance of disclosure directives which authorize a person or persons to disclose personal health information held in a health information bank. ${ }^{122}$ The DSC is further empowered to make determinations regarding when it is in the public interest to disclose protected information for a health research purpose.

The composition of the DSC includes mandatory representation from relevant government ministries, regional health boards, provincial health services authority, professional medical, pharmacy, and nursing colleges, as well as a health researcher, a pharmaceutical researcher, and up to three public representatives. ${ }^{123}$ The Act also allows for the appointment of two more unspecified members. This membership structure allows flexibility in shaping and altering the composition of the Committee to include expertise in any area of pressing significance. Another noteworthy feature of the DSC is that, unlike REBs, the Act authorizes the Minister to pay remuneration to its members for their service and to reimburse "reasonable and necessary travel and out of pocket expenses." ${ }^{24}$

A major criticism of this approach is that it will add another level of research oversight to a very bureaucratized governance system, thus burdening researchers with more paperwork and rules. Multiple provincial DACs will likely exacerbate this problem and create barriers for inter-provincial research collaboration. Furthermore, if DSC review is applied solely to genetic information (the British Columbia E-Health Act, which is intended to apply to electronic health information databases), this might be perceived as creating the impression that genetic information is exceptional or deserving of unique scrutiny. However, these concerns can be mitigated by adopting the following strategies. First, a national data access committee, similar to the Stem Cell Oversight Committee, ${ }^{125}$ could be established to handle research protocols that raise serious privacy concerns (as identified by REBs). Second, the role of provincial DACs can be limited to monitoring institutional data access policies and periodic compliance reviews of REB public interest determinations. Finally, different aspects of governance, including health data protection legislation and research

A Health Information Bank is a database designated as such by the Minister of Health, and in accordance with the Act. See generally BC E-Health Act, supra note 70, ss 1, 3-4.

Ibid, s 13(2).

Ibid, ss 11-13.

Ibid, s 12.

Ibid, s 12(4)(b).

The Stem Cell Oversight Committee is a national body created to conduct ethical review of research funding applications dealing with human pluripotent stem cell research: Canadian Institutes of Health Research, Terms of Reference - Stem Cell Oversight Committee (17 November 2009), online: Canadian Institutes of Health Research <http://www.cihr-irsc.gc.ca/e/20410.html>. 
ethics policies, could be unified into a single, comprehensive strategy administered by a regulatory body with commensurate expertise. ${ }^{126}$

\section{CONCLUSION}

Genetic research holds tremendous potential for significant health, economic, and other societal benefits. Recognizing this potential, policy-makers have sought, rightly so, to promote the research as a public good. In hopes of realizing these benefits, policies designed to encourage and advance this research, such as open access policies and the relaxation of traditional informed consent standards, have been embraced by both policy-makers and the research community. While the view that it is in the public interest to promote and facilitate genetic research is supported by Canadian jurisprudence, there is corresponding support for and emphasis on promoting and protecting the public interest in individual privacy. However, the latter objective is not reflected or is understated in existing genetic research policies, a situation that minimizes both the value of robust privacy protections and the considerable risk of privacy invasions in this context.

As genetic research moves forward, constructive governance reforms, such as the inclusion of persons with appropriate privacy expertise in the research review and policy development process, are needed to ensure adequate privacy protection and to maintain the legally required balance between vital public interests in research and in privacy. Such reforms will also impact positively on the progress of and public trust in genetic research by ensuring that activities and developments in the field are not compromised by a lack of commitment to individual privacy or a lack of attention to privacy issues and concerns. 


\section{Box A: Factors Guiding Public InTERest Determinations IN THE ConTEXT OF Alberta PRIVACY Legislation ${ }^{127}$}

1. Will the records contribute to the public understanding of, or to debate on or resolution of, a matter or issue that is of concern to the public or a sector of the public, or that would be, if the public knew about it? The following may be relevant:

a. Have others besides the applicant sought or expressed an interest in the records?

b. Are there other indicators that the public has or would have an interest in the records?

2. Is the applicant motivated by commercial or other private interests or purposes, or by a concern on behalf of the public or a sector of the public? The following may be relevant:

a. Do the records relate to a conflict between the applicant and government?

b. What is the likelihood that the applicant will disseminate the contents of the records?

3. If the records are about the process or functioning of government, will they contribute to open, transparent, and accountable government? The following may be relevant:

a. Do the records contain information that will show how the Government of Alberta or a public body reached or will reach a decision?

b. Are the records desirable for the purpose of subjecting the activities of the Government of Alberta or a public body to scrutiny?

c. Will the records shed light on an activity of the Government of Alberta or a public body that have been called into question? 
TABLE 1:

Examples of Public Interest ObJectives, By Province

\begin{tabular}{|c|c|}
\hline Province & Example \\
\hline Ontario & 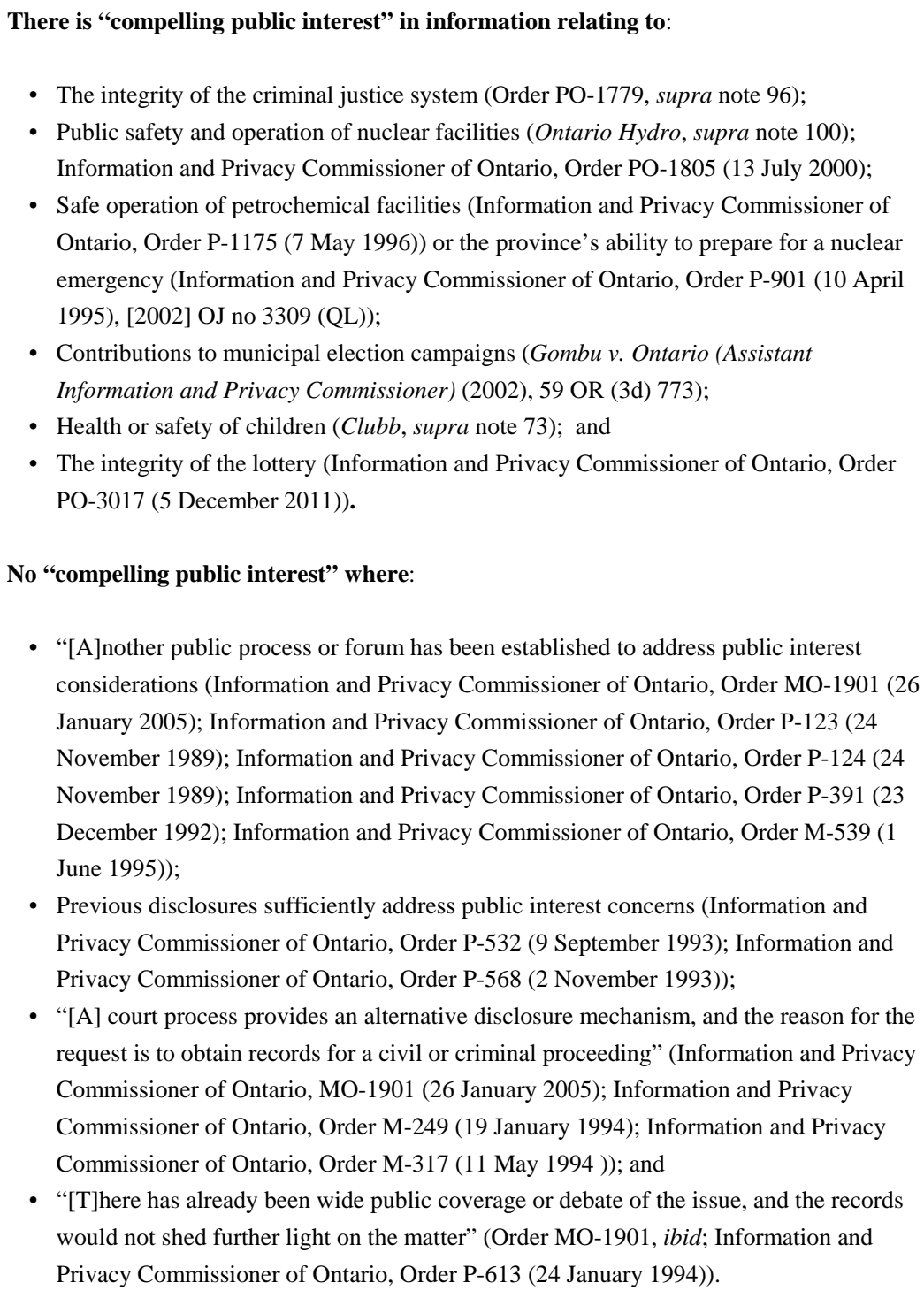 \\
\hline
\end{tabular}




\begin{tabular}{|c|c|}
\hline Province & Example \\
\hline $\begin{array}{l}\text { British } \\
\text { Columbia }\end{array}$ & $\begin{array}{l}\text { A public interest exists where: } \\
\text { - Financial information relates to a publicly funded institution that is clearly a public } \\
\text { body within the meaning of the BC FIPPA (Tromp v. British Columbia (Information } \\
\text { and Privacy Commissioner), [2000] BCJ no } 761 \text { (QL), BCSC 598); and } \\
\text { - The information would permit a representative plaintiff to contact other individuals } \\
\text { involved in a class action lawsuit (Dalhuisen (Guardian ad litem of) v. Maxim's Bakery } \\
\text { Ltd., } 2002 \text { BCSC 1146, } 4 \text { BCLR (4th) 196, leave to appeal granted } 2002 \text { BCCA 541). } \\
\text { No public interest exists where: } \\
\text { - Information relates to a shift in public policy (Office of the Information and Privacy } \\
\text { Commissioner for British Columbia, Order 02-38 (26 July 2002)); } \\
\text { - Information “add[s] little or nothing ... to that which is already known” (Order 02-38, } \\
\text { ibid at para 67); } \\
\text { - There is no urgent and compelling need for disclosure or no element of temporal } \\
\text { urgency (Office of the Information and Privacy Commissioner for British Columbia, } \\
\text { Order F12-04 (2 February 2012); Order 02-38, ibid; Office of the Information and } \\
\text { Privacy Commissioner for British Columbia, Order F07-04 (7 March 2007); Office of } \\
\text { the Information and Privacy Commissioner for British Columbia, Order F09-04 (2 } \\
\text { April 2009)); } \\
\text { - The information does not “facilitate effective use of various means of expressing public } \\
\text { opinion and making political choices” (Order 02-38, ibid at para 66; Office of the } \\
\text { Information and Privacy Commissioner for British Columbia, Order F07-23 (29 } \\
\text { November 2007)); or } \\
\text { - The information is sought to “test ... the accuracy or truthfulness of statements made ... } \\
\text { by public figures,” which is not urgent or compelling (Order F07-04, supra note 142 at } \\
\text { para 14). }\end{array}$ \\
\hline Alberta & $\begin{array}{l}\text { A public interest exists where: } \\
\text { - Information relates to accident reports concerning elevators and escalators and thus } \\
\text { public health and safety (Alberta, Information and Privacy Commissioner, Order 97- } \\
001 \text { (12 June 1997)). } \\
\text { No public interest exists where: } \\
\text { - “[E]mergency-like circumstances” do not exist because the applicant is aware of the } \\
\text { risk (Alberta, Information and Privacy Commissioner, Order 97-009 (28 October } \\
\text { 1997)); }\end{array}$ \\
\hline
\end{tabular}




\begin{tabular}{|c|c|}
\hline Province & Example \\
\hline $\begin{array}{l}\text { Alberta } \\
\text { con't }\end{array}$ & $\begin{array}{l}\text { - Information sought (regarding courthouse security) does not relate to the interests } \\
\text { alleged (ability to visit courthouses and general risk to public safety) (Alberta, Office of } \\
\text { the Information and Privacy Commissioner, Order F2010-004 (6 July 2010)); } \\
\text { - Applicant merely asserts interest in information without establishing that it is a matter } \\
\text { of public interest (Alberta, Information and Privacy Commissioner, Order 97-018 (12 } \\
\text { February 1998)); or } \\
\text { - The risk of harm has passed and suggestions that future incidents could pose a risk are } \\
\text { speculative (Alberta, Office of the Information and Privacy Commissioner, Order } \\
\text { F2012-03 (20 January 2012)). }\end{array}$ \\
\hline
\end{tabular}

